\title{
IMPLEMENTASI MODEL PEMBELAJARAN KOOPERATIF TIPE STUDENT TEAM ACHIEVEMENT DIVISION (STAD) UNTUK MENINGKATKAN AKTIVITAS DAN HASIL BELAJAR MATEMATIKA KELAS VI SDN BAGELENAN 03 SRENGAT BLITAR TAHUN PELAJARAN 2017/2018
}

\author{
Martini \\ SDN Bagelenan 03 Srengat Blitar
}

\begin{abstract}
The initial observation showed that there were problems in mathematics. That is about the low activity and learning outcomes of Class VI students at SDN Bagelenan 03 Srengat Blitar. This problem is because when the learning process takes place, students only listen, record and obey the teacher's commands, so that students feel bored. The teacher only uses the lecture method without varying the other methods. The best solution about these problems is cooperative learning with STAD type. This research aiming to increasing the activity and learning outcomes of mathematics in class VI students subject matter of fraction counting operations in SDN Bagelenan 03. The type of research used is classroom action research. Data collection uses the method of observation, tests, documentation, and interviews. Data collected in the form of analysis of students' answers to the value of the first cycle test and second cycle test. The application of cooperative learning STAD type subject matter of fraction counting operations can be concluded that the activities and learning outcomes in the first cycle have met the minimum completeness criteria, while in the second cycle have increased again. The second cycle is a stabilization cycle because in the first cycle has been completed.
\end{abstract}

Keywords: STAD, Learning Outcomes, Student Activities

\section{ABSTRAK}

Observasi awal menunjukkan adanya permasalahan dalam matematika yaitu rendahnya aktivitas dan hasil belajar siswa kelas VI di SDN Bagelenan 03 Srengat Blitar. Permasalahan ini dikarenakan pada saat proses pembelajaran berlangsung, siswa hanya mendengarkan, mencatat dan mematuhi perintah guru, sehingga siswa merasa bosan. Guru hanya menggunakan metode ceramah tanpa memvariasikan metode yang lain. Masalah tersebut perlu diatasi melalui penerapan model pembelajaran kooperatif tipe STAD. Penelitian ini diangkat dengan tujuan untuk meningkatkan aktivitas dan hasil belajar matematika pada siswa kelas VI materi pokok operasi hitung pecahan di SDN Bagelenan 03 Srengat Blitar dengan penerapan pembelajaran kooperatif tipe STAD. Jenis penelitian yang digunakan dalam penelitian ini adalah penelitian tindakan kelas (PTK). Pengumpulan data menggunakan metode observasi, tes, dokumentasi, dan wawancara. Data yang dikumpulkan berupa analisis jawaban siswa terhadap nilai tes siklus I dan nilai tes siklus II, dan hasil analisis aktivitas siswa selama proses pembelajaran matematika berlangsung. Penerapan pembelajaran kooperatif tipe STAD materi pokok operasi hitung pecahan dapat disimpulkan bahwa aktivitas dan hasil belajar pada siklus I sudah memenuhi kriteria ketuntasan minimal, sedangkan pada siklus II aktivitas dan hasil belajar siswa kembali mengalami peningkatan. Pelaksanaan siklus II ini merupakan siklus pemantapan karena pada siklus I sudah tuntas, maka siklus II dilakukan sebagai pemantapan.

Kata Kunci : Model STAD, Hasil Belajar Matematika, Aktivitas Siswa

\footnotetext{
${ }^{1)}$ Korespondensi : Martini. SDN Bagelenan 03 Srengat Blitar Email : Martini_pjj@yahoo.co.id
} 
PENDAHULUAN

Pendidikan secara umum adalah segala upaya yang direncanakan untuk mempengaruhi orang lain, baik individu, kelompok atau masyarakat, sehingga mereka melakukan apa yang diharapkan oleh pelaku pendidikan (Notoatmojo, 2003:16). Pendidikan dilakukan dengan terencana agar terwujud suasana belajar dan proses pembelajaran peserta didik yang aktif dalam mengembangkan potensinya. Pendidikan memberikan pengetahuan, keterampilan dan sikap kepada anak didiknya secara lengkap dengan strategi yang tepat. Strategi pelaksanaan pendidikan dilakukan dalam bentuk kegiatan bimbingan, pengajaran, dan latihan. Bimbingan pada hakekatnya adalah pemberian bantuan, arahan, motivasi, nasehat dan penyuluhan agar siswa mampu mengatasi, pemecahan masalah, menanggulangi kesulitan sendiri. Pengajaran adalah bentuk kegiatan di mana terjalin hubungan interaksi dalam proses belajar dan mengajar antara tenaga kependidikan (khususnya guru/pengajar) dan peserta didik untuk mengembangkan perilaku sesuai dengan tujuan pendidikan. Pelatihan prinsipnya adalah sama dengan pengajaran, khususnya untuk mengembangkan keterampilan tertentu.
Produk yang ingin dihasilkan oleh proses pendidikan adalah berupa lulusan yang memiliki kemampuan melaksanakan peran-peranannya untuk masa yang akan datang. Peranan yang bertalian dengan jabatan dan pekerjaan tertentu, tentunya bertalian dengan kegiatan pembangunan di masyarakat. Pendidikan merupakan suatu proses dalam rangka mempengaruhi peserta didik supaya mampu menyesuaikan diri sebaik mungkin dengan lingkungannya, sehingga menimbulkan perubahan dalam dirinya yang memungkinkannya berfungsi secara maksimal dalam kehidupan masyarakat. Pengajaran bertugas mengarahkan proses ini agar sasaran dari perubahan itu dapat tercapai sebagaimana yang diinginkan.

Pendidikan di Indonesia meliputi pendidikan formal dan pendidikan non formal. Pendidikan formal biasanya dinaungi di sekolah. Siswa seringkali menganggap sekolah sebagai tempat bermain dan tempat menghabiskan uang jajan. Ada sebagian siswa beranggapan bahwa bersekolah hanya untuk mendapatkan ijazah tanpa tau tujuan dari sekolah. Padahal, sekolah merupakan suatu wadah pendidikan formal yang dikondisikan bagi anak didik yang bertujuan tidak hanya untuk pencapaian ilmu, namun juga mampu menyiapkan 
anak didik dengan moral, etika yang diberikan guna memasuki tahapan kehidupan selanjutnya secara berharkat dan bermartabat. Jenjang sekolah di Indonesia meliputi SD, SMP, SMA. Jenjang sekolah pertama adalah Sekolah Dasar, dimana Sekolah Dasar memiliki peranan penting dalam membentuk moral dan etika pada anak. Menurut Suharjo (2006:26) "Sekolah Dasar (SD) pada dasarnya merupakan lembaga pendidikan yang menyelenggarakan program pembelajaran enam tahun bagi anak-anak usia 6-12 tahun." Selama enam tahun mengikuti program pembelajaran di SD, siswa diharuskan dapat memahami lima mata pelajaran wajib, yaitu; Matematika, Bahasa Indonesia, Ilmu Pengetahuan Sosial (IPS), Pendidikan Kewarganegaraan (PKn) dan Ilmu Pengetahuan Alam (IPA). Pembelajaran menurut Resnik yang dikutip dalam Martorella, 1991, menjelaskan Pembelajaran tidak dapat diartikan secara sederhana sebagai alih informasi pengetahuan dan ketrampilan ke dalam benak siswa. Pembelajaran yang efektif seyogyanya membantu siswa menempatkan diri dalam situasi di mana mereka mampu melakukarn konstruksikonstruksi pemikirannya dalam situasi wajar, alami, dan mampu mengekpresikan dirinya secara tepat apa yang mereka rasakan dan mampu melaksanakannya.

Proses pembelajaran matematika di Sekolah Dasar selama ini lebih ditekankan kepada penguasaan bahan/materi pelajaran sebanyak mungkin oleh guru, sehingga suasana belajar bersifat kaku, dan terpusat pada satu arah serta tidak memberikan kesempatan bagi siswa untuk belajar lebih aktif. Budaya belajar lebih ditandai oleh budaya hafalan dari pada budaya berfikir, akibatnya siswa menganggap bahwa pelajaran matematika adalah pelajaran yang menyulitkan. Hal tersebut mengandung pengertian bahwa pembelajaran selain harus mampu memotivasi siswa untuk aktif, kreatif dan inovatif, juga harus disesuaikan dengan tingkat perkembangan siswa itu sendiri.

Kenyataan di lapangan menunjukkan hal yang berbeda dengan konsep di atas, dalam praktek-praktek pembelajaran matematika di SD. Observasi awal pada bulan Januari 2018, menunjukkan permasalahan dalam pembelajaran matematika pada siswa kelas VI di SDN Bagelenan 03 Srengat Blitar bahwa aktivitas dan hasil belajar siswa masih rendah. Aktivitas siswa yang masih rendah dapat dilihat selama pembelajaran matematika, siswa hanya mendengarkan, mencatat, dan mematuhi 
Martini: Implementasi Model Pembelajaran Kooperatif Tipe Student Team Achievement Division (Stad) Untuk Meningkatkan Aktivitas Dan Hasil Belajar Matematika Kelas Vi Sdn Bagelenan 03 Srengat Blitar Tahun Pelajaran 2017/2018

perintah guru sehingga siswa merasa jenuh dan bosan selama pembelajaran berlangsung hal ini yang menyebabkan hasil belajar siswa menjadi sangat rendah dan tidak mencapai standar ketuntasan dalam belajar. Dari hasil wawancara yang di lakukan oleh peneliti kepada guru kelas VI SDN Bagelenan 03 Srengat Blitar di dapatkan hasil sekitar 25 persen siswa yang kurang memahami materi pokok operasi hitung pecahan, dikarenakan faktor yang bersumber dari siswa yang kemampuannya kurang memahami operasi hitung pecahan, dan faktor dari guru, kebanyakan guru hanya menggunakan metode ceramah terus menerus tanpa memadukan dengan metode lain sehingga siswa merasa bosan dan tidak memperhatikan sama sekali materi yang diajarkan oleh guru. Sedangkan seorang siswa dikatakan tuntas dalam belajar bila telah mencapai skor $\geq$ 75 dari skor maksimal 100. Dan suatu kelas dikatakan tuntas belajar bila terdapat $85 \%$ yang telah mencapai skor $\geq 75$ (standar mata pelajaran matematika SDN Bagelenan 03 Srengat kabupaten Blitar), Rendahnya kualitas hasil pembelajaran siswa pada mata pelajaran matematika merupakan indikasi bahwa tujuan yang ditentukan dalam kurukulum matematika belum tercapai secara optimal. Secara umum kenyataan ini dapat dilihat dari hasil ujian semester dua kelas VI di SDN Bagelenan 03 Srengat Blitar sangat memprihatinkan. Meskipun berbagai upaya telah dilakukan oleh guru namun hasilnya masih jauh dari harapan.

Berdasarkan latar belakang di atas, tujuan dari penelitin ini adalah untuk mendeskripsikan peningkatan aktivitas belajar matematika materi pokok operasi hitung pecahan dengan penerapan pembelajaran kooperatif tipe STAD pada siswa kelas VI SDN Bagelenan 03 Srengat Blitar dan untuk mendeskripsikan peningkatan hasil belajar matematika materi pokok operasi hitung pecahan dengan penerapan pembelajaran kooperatif tipe STAD pada siswa kelas VI SDN SDN Bagelenan 03 Srengat Blitar

Salah satu model pembelajaran yang dapat dijadikan alternatif solusi adaalh STAD. STAD (Student Teams Achievement Division) menurut Slavin (pembelajaran kooperatif model STAD, siswa dikelompokkan dalam kelompok belajar yang beranggotakan empat atau lima orang siswa yang merupakan campuran dari kemampuan akademik yang berbeda, sehingga setiap kelompok terdapat siswa yang berprestasi tinggi, sedang dan rendah. Pada model STAD siswa dikelompokkan secara heterogen, 
kemudian siswa yang pandai menjelaskan kepada anggota yang lain sampai mengerti. Model kooperatif tipe STAD merupakan model yang menekankan pada aktivitas dan interaksi di antara siswa untuk saling memotivasi dan saling membantu dalam menguasai materi pembelajaran guna mencapai prestasi yang maksimal.

Pembelajaran yang efektif adalah pembelajaran yang menyediakan kesempatan belajar sendiri atau melakukan aktivitas sendiri. Aktivitas merupakan prinsip atau asas yang sangat penting dalam interaksi belajar mengajar (Sardiman, 2006: 96). Saat pembelajaran belangsung siswa mampu memberikan umpan balik terhadap guru. Sardiman (2006: 100) menyatakan bahwa aktivitas belajar merupakan aktivitas yang bersifat fisik maupun mental. Dalam kegiatan belajar keduanya saling berkaitan. Oemar Hamalik (2009: 179) menyatakan bahwa aktivitas belajar merupakan kegiatan yang dilakukan oleh siswa dalam kegiatan pembelajaran. Aktivitas belajar dapat terwujud apabila siswa terlibat belajar secara aktif. Martinis Yamin (2007: 82) mendefinisikan belajar aktif sebagai usaha manusia untuk membangun pengetahuan dalam dirinya. Pembelajaran akan menghasilkan suatu perubahan dan peningkatan kemampuan, pengetahuan dan ketrampilan pada diri siswa. Siswa mampu menggali kemampuannya dengan rasa ingin tahunya sehingga interaksi yang terjadi akan menjadi pengalaman dan keinginan untuk mengetahui sesuatu yang baru.

Aktivitas belajar yang dimaksud adalah aktivitas belajar siswa yang berupa tingkah laku yang melibatkan proses berfikir yang ditunjukkan untuk siswa sebagai akibat keiginan untuk berbuat dan bekerja. Dalam pembelajaran ini diambil lima jenis aktivitas yaitu: Visual activities berupa dapat memilih dan dan memanfaatkan sumber pelajaran yang tepat, Oral activities berupa kemampuan mengelurkan pendapat, Emotional activities berupa kerjasama dalam kelompok, Motor activities presentasi kelompok.

\section{METODE PENELITIAN}

Penelitian ini akan di laksanakan pada bulan Januari 2018 - April 2018 semester dua tahun ajaran 2017/2018. Jenis penelitian yang digunakan dalam penelitian ini adalah Penelitian Tindakan Kelas (Classroom Action Research). Penelitian bersifat kolaboratif yang didasarkan pada masalah yang muncul dalam pembelajaran matematika di SDN 
Bagelenan 03 Srengat Blitar. Jenis penelitian ini menggunakan model penelitian Hopkins yang berbentuk spiral dengan tahapan penelitian tindakan pada suatu siklus yang meliputi perencanaan (planning), tindakan (action), pengamatan (observation), dan refleksi (reflection). Adapun desain silkus Hopkins adalah sebagai berikut,

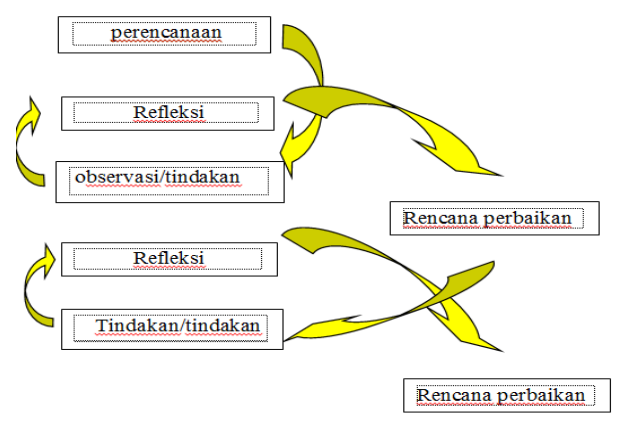

\section{Gambar 1 Penelitian Tindakam Kelas model Hopkins (dalam Supardi, 2014:105)}

Penelitian ini direncanakan dalam dua siklus yang. Jika pada siklus pertama hasil belajar belum mencapai ketuntasan maka dilanjutkan pada siklus kedua, namun apabila dari refleksi siklus pertama telah mencapai ketuntasan klasikal, maka siklus selanjutnya dilakukan sebagai pemantapan.

Metode pengumpulan data adalah caracara yang dilakukan oleh peneliti untuk mengumpulkan data. Pengumpulan data tersebut bertujuan untuk memperoleh bahan-bahan yang relevan dan akurat agar dapat digunakan dengan tepat. Dalam penelitian ini metode-metode yang digunakan antara lain: metode observasi; metode wawancara; metode dokumentasi; metode tes.

Analisis data digunakan untuk menyusun dan mengolah data yang terkumpul sehingga dapat ditarik data yang terkumpul, sehingga dapat ditarik kesimpulan. Analisis data dalam penelitian ini adalah deskriptif kualitatif yaitu peneliti berusaha memaparkan data tentang aktivitas dan hasil belajar siswa yang diperoleh dari hasil pelaksanaan pembelajaran kooperatif tipe STAD. Data tersebut diperoleh dari hasil tes, observasi, wawancara dad dokumentasi dengan harapan dapat mendukung analisis penelitian, sehingga dapat menggambarkan secara rinci mengenai hasil penelitian. Adapun data yang di anlisis adalah sebagai berikut:

Persentase keaktifan siswa selama proses pembelajaran kooperatif model STAD berlangsung yang dianalisis dengan rumus:

$P=\frac{m}{M} \times 100 \%$

Keterangan :

$P=$ Persentase keaktifan siswa

$m=$ jumlah skor yang dicapai siswa

$M=$ jumlah skor maksimal 
Dengan kriteria aktivitas seperti tabel berikut ini:

Tabel 1.1 Kriteria Aktivitas Siswa

\begin{tabular}{cc}
\hline $\begin{array}{c}\text { Persentase } \\
\text { Aktivitas }\end{array}$ & Kriteria \\
\hline $75 \% \leq \mathrm{P}_{\mathrm{a}} \leq 100 \%$ & Sangat aktif \\
\hline $50 \% \leq \mathrm{P}_{\mathrm{a}}<75 \%$ & Aktif \\
\hline $25 \% \leq \mathrm{P}_{\mathrm{a}}<50 \%$ & Sedang \\
\hline $1 \% \leq \mathrm{P}_{\mathrm{a}}<25 \%$ & Kurang aktif \\
\hline $0 \%$ & $\begin{array}{c}\text { Sangat kurang } \\
\text { aktif }\end{array}$ \\
\hline & (Slameto, 1999:116)
\end{tabular}

Persentase ketuntasan hasil belajar siswa dengan pembelajaran tipe STAD yang dianalisis dengan rumus:

$P=\frac{n}{N} \times 100 \%$

Keterangan

$P=$ Persentase ketuntasan siswa

$n=$ Jumlah siswa yang memiliki skor $\geq 70$

dari skor maksimum 100

$N=$ Jumlah seluruh siswa

Kriteria ketuntasan belajar siswa adalah:

ketuntasan perorangan, seorang siswa dikatakan tuntas belajar apabila telah mencapai skor $\geq 75$ dari skor maksimal 100. Ketuntasan klasikal, suatu kelas dinyatakan tuntas apabila terdapat minimal $85 \%$ telah mencapai ketuntasan individual $\geq 75$ dari skor maksimal 100 .
Tabel 1.2 Kategori Persentase Peningkatan Hasil Belajar Siswa

\begin{tabular}{cc}
\hline Skor rata-rata & Kategori \\
\hline $\mathrm{P} \geq 90 \%$ & Sangat baik \\
\hline $80 \% \leq \mathrm{P}<90 \%$ & Baik \\
\hline $60 \% \leq \mathrm{P}<80 \%$ & Cukup baik \\
\hline $50 \% \leq \mathrm{P}<60 \%$ & Kurang baik \\
\hline & (Slameto, 1990:119)
\end{tabular}

\section{HASIL DAN PEMBAHASAN}

Hasil analisi aktivitas siswa selama proses pembelajaran berlangsung dengan enerapan pembelajaran kooperatif tipe STAD materi pokok operasi hitung pecahan diperoleh data aktivitas seperti yang tampak pada tebel di bawah ini.

Tabel 1.3 Pembelajaran Siklus I dan Siklus II

\begin{tabular}{llll}
\hline & \multicolumn{1}{c}{$\begin{array}{c}\text { Aspek } \\
\text { No. }\end{array}$} & \multicolumn{2}{c}{ Pembelajaran } \\
\cline { 3 - 4 } & $\begin{array}{c}\text { Aktivitas } \\
\text { Siswa }\end{array}$ & Siklus I & Siklus II \\
\hline 1. & $\begin{array}{l}\text { Memperhatikan } \\
\text { pelajaran }\end{array}$ & $73,68 \%$ & $81,37 \%$ \\
\hline 2. & $\begin{array}{l}\text { Mengeluarkan } \\
\text { pendapat }\end{array}$ & $77,40 \%$ & $80,18 \%$ \\
\hline 3. & $\begin{array}{l}\text { Diskusi dalam } \\
\text { kelompok }\end{array}$ & $69,11 \%$ & $75,74 \%$ \\
\hline 4. & $\begin{array}{l}\text { Menyelesaikan } \\
\text { soal dalam } \\
\text { LKK }\end{array}$ & $71,62 \%$ & $78,64 \%$ \\
\hline & Rata-rata & $72,95 \%$ & $78,98 \%$ \\
\hline
\end{tabular}

Berdasarkan hasil analisis aktivitas siswa pada tabel diatas dengan penerapan pembelajaran kooperatif tipe STAD secara keseluruhan dapat dikatakan aktif, karena dapat dilihat dari persentase keaktifan siswa secara keseluruhan yaitu diperoleh 
Martini: Implementasi Model Pembelajaran Kooperatif Tipe Student Team Achievement Division (Stad) Untuk Meningkatkan Aktivitas Dan Hasil Belajar Matematika Kelas Vi Sdn Bagelenan 03 Srengat Blitar Tahun Pelajaran 2017/2018

hasil pada siklus $\mathrm{I}=72,95 \%$, sedangkan pada siklus II aktivitas siswa mengalami peningkatan yaitu $78,98 \%$ termasuk kedalam kriteria aktivitas siswa yang aktif.

Berdasarkan analisis hasil belajar siswa, hasil belajar siswa pada siklus I dan siklus II mengalami peningkatan, adapun hasil belajar siswa dapat dilihat pada tabel tingkat ketuntasan belajar siswa sebelum tindakan, siklus I dan siklus II di bawah ini.

Tabel 1.4 Prosentase Hasil Siklus I dan Siklus II

\begin{tabular}{ccccccc}
\hline \multirow{2}{*}{ Nilai } & \multicolumn{2}{c}{ Pra Siklus } & \multicolumn{2}{c}{ Siklus I } & \multicolumn{2}{c}{ Siklus I } \\
\cline { 2 - 7 } & \multirow{2}{*}{ Jml Siswa } & Persentase & \multirow{2}{*}{ Jml Siswa } & Persentase & $\begin{array}{c}\text { Jml } \\
\text { Siswa }\end{array}$ & \multirow{2}{*}{ Persentase } \\
\hline$\geq 75$ & 3 & $17,65 \%$ & 13 & $76,47 \%$ & 16 & $94,12 \%$ \\
\hline$\leq 75$ & 14 & $82,35 \%$ & 4 & $23,53 \%$ & 1 & $5,88 \%$ \\
\hline Jml & 17 & $100 \%$ & 17 & $100 \%$ & 17 & $100 \%$ \\
\hline
\end{tabular}

Tabel diatas menunjukkan bahwa tingkat ketuntasan belajar siswa pada pra siklus secara klasikal sebesar $17,65 \%$, dari 17 siswa kelas VI hanya 3 siswa yang tuntas. Tindakan siklus I tingkat ketuntasan hasil belajar siswa secara klasikal mengalami peningkatan menjadi $76,47 \%$ dari 17 siswa kelas VI terdapat 13 siswa yang tuntas.

Pada tabel 1.4 juga menunjukkan Hasil observasi siklus I, siswa sudah terlihat aktif, meskipun pembelajaran yang diterapkan oleh oleh guru belum pernah diterapkan sebelumnnya, tetapi sebelum pembelajaran dimulai terlebih dahulu guru menjelaskan tentang langkah-langkah dalam pembelajaran pembelajaran kooperatif tipe STAD sehingga pada saat pembelajaran berlangsung siswa tidak mengalami kesulitan dalam bekerja sama dengan anggota kelompoknya masingmasing. Dari 17 siswa, 94,12\% dari siswa kelas VI atau 16 siswa yang tuntas, dan yang tidak tuntas ada 1 siswa.

Pada tabel 1.4 juga mendeskripsikan Pelaksanan siklus II ini adalah sebagai pementapan dari siklus I karena pada siklus I sudah mencapai ketuntasan belajar klasikal, pada siklus II masih tetap menggunakan model yang sama pada proses pembelajaran yaitu dengan penerapan model pembelajaran kooperatif tipe STAD. Ketuntasan yang diperoleh pada siklus II ini sebesar 94,12\%, sedangkan tingkat aktivitas belajar siswa 
meningkat dan memenuhi kriteria pada pembelajaran matematika dengan ketuntasan belajar secara klasikal.

materi pokok operasi hitung pecahan

Berdasarkan hasil wawancara yang dilakukan kepada guru kelas VI dan siswa kelas VI, tanggapan mereka bahwa terbukti dapat meningkatkan aktivitas dan hasil belajar matematika pada siswa kelas VI SDN Bagelenan 03 Srengat Blitar. penerapan model pembelajaran kooperatif tipe STAD dapat meningkatkan aktivitas siswa selama pembelajaran berlangsung. Penerapan pembelajaran kooperetif tipe STAD ini dapat membuat siswa merasa senang karena siswa tidak hanya mendengarkan penjelasan dari guru tetapi mereka bekerja sama dan saling membantu dalam satu kelompok jadi semua siswa itu terlihat aktif.

Berdasarkan pembahasan di atas dapat diketahui bahwa hasil dari penelitian ini menunjukkan bahwa dengan penerapan model pembelajaran kooperatif tipe STAD

\section{PENUTUP}

\section{Simpulan}

Penerapan pembelajaran kooperatif tipe STAD materi pokok operasi hitung pecahan dapat disimpulkan bahwa aktivitas dan hasil belajar pada siklus I sudah memenuhi kriteria ketuntasan minimal, sedangkan pada siklus II aktivitas dan hasil belajar siswa kembali mengalami peningkatan. Pelaksanaan siklus II ini merupakan siklus pemantapan karena pada siklus I sudah tuntas, maka siklus II dilakukan sebagai pemantapan

\section{DAFTAR PUSTAKA}

Akbar, sa'dun. 2013. Instrumen Perangkat Pembelajaran. Bandung: Remaja rosda karya. Arikunto, S. 2006. Prosedur Suatu Pendekatan Praktek. Jakarta: Rineka Cipta Arsyad, Azhar.2013. Media pembelajaran. Jakarta: PT Raja Grafindo Persada . Asnawir dan M. Basyaruddin Usman. 2002. Media Pembelajaran. Jakarta: Ciputat Press. Hamalik, Oemar.2003. Kurikulum dan Pembelajaran. Jakarta: Bumi aksara.

Hobri. 2007. Penelitian Tindakan Kelas untuk Guru dan Praktisi. Jember: UPTD Balai Pengembangan Pendidikan Universitas Jember. 
Martini: Implementasi Model Pembelajaran Kooperatif Tipe Student Team Achievement Division (Stad) Untuk Meningkatkan Aktivitas Dan Hasil Belajar Matematika Kelas Vi Sdn Bagelenan 03 Srengat Blitar Tahun Pelajaran 2017/2018

Mahmud. 2011. Metode Penelitian Pendidikan. Bandung: Pustaka Setya

Notoatmojo. 2003. Pendidikan dan Perilaku kesehatan. Jakarta: Rineka cipta

Narkubo dan Ahmadi. 2009. Metodologi Penelitian. Jakarta: Bumi Aksara

Rusman. 2010. Model-Model Pembelajaran. Jakarta: Grafindo Persabda.

Sadiman, Arief S, dkk. 2014. Media Pendidikan: Pengertian, Pengembangan dan pemanfaatannya. Jakarta: Rajawali Pers.

Setyosari, Punaji. 2013. Metode Penelitian Pendidikan dan Pengembangan. Jakarta: PT. Kharisma Putra Utama

Slameto. 1999. Evaluasi Pendidikan. Jakarta: PT. Bumu Aksara.

Supardi. 2010. Penelitian Tindakan Kelas. Jakarta: Bumi Aksara.

Wardani, Igak. Penelitian Tindakan Kelas. Jakarta: Universitas Terbuka 